\title{
Corporate Strategies In The Post-Transition Economy: The Case Of Slovenian Companies
}

Matej Lahovnik, University of Ljubljana, Slovenia

\begin{abstract}
This paper argues that unrelated diversification strategies outperform related diversification strategies. The author identifies three phases of the internationalisation process. More detailed analyses of the internationalisation process shows that companies are trying to develop more complex forms of international business activities. The author also identifies four groups of competencies that are the cornerstones of corporate strategies. This study reveals that $40.6 \%$ of companies diversified through external means, $36.2 \%$ diversified through internal means, while $23.2 \%$ diversified through both internal and external methods. There appears to be no statistically significant performance differences among companies regarding external and internal growth strategies. Internal growth and joint ventures are the most important forms of diversification. These companies also tend to develop various forms of long-term strategic cooperation. This process can be crucial for developing competitive advantages. By comparing the performance of companies regarding ownership structure, the author found that companies with international ownership structure performed better. In other words, foreign ownership had a positive influence on company performance.
\end{abstract}

Keywords: Slovenia; corporate strategy; diversification strategy

\section{INTRODUCTION}

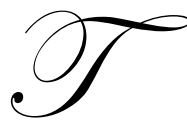

his paper deals with some factors determining performance of corporate strategies in the PostTransition economy in Slovenia. The article proceeds as follows. The next section deals shortly with some important theoretical issues. The third section presents the characteristics of the Slovenia's business environment. The empirical results of this study are presented in the fourth section. In conclusion the author discusses the results and some implications for managers. Slovenia is a small open economy. It has become a member of the European Union in 2004 and a member of OECD in 2010. Among those transition economies that entered the new larger Europe, the Slovenian economy is the most developed, with a GDP of approx. 90\% of average GDP in the European Union and therefore bigger than in some older EU member states like Portugal. Slovenia has become a 'benchmark' for other post-transitional economies in the region due to its successful transition process. Not only it is a member of EU and OECD on one hand but, as a former Yugoslav republic, it offers a starting point for strategic investors in the region of South-eastern Europe on the other.

The principal concern of corporate strategy is to identify the business areas in which a company should participate in order to maximise its long-run profitability (Hill, Jones, 1998). To create value, a corporate strategy should enable a company or its business units to perform one or more of the value creation functions at a lower cost or perform one or more of the value creation functions in a way that allows differentiation. Thus, a company's corporate strategy should help in the process of establishing a distinctive competency and competitive advantage at the business level. It is a link that many companies appear to have lost of sight of.

The empirical research was based on a fully-structured interview that was prepared with pre-coded responses. A firm had to have specific characteristics to fall within the research sample: 
- $\quad$ it should have had at least 250 employees;

- $\quad$ it should have had at least USD 5 million in annual income; and

- $\quad$ it should have been a joint-stock company.

The author mailed the questionnaire to 185 companies in Slovenia. Sixty-nine companies responded which gives us 37.3 percent respond rate. The responses of the top managers were recorded on a standardised Likert scale.

The author compared the performance of the various corporate strategies by using four different criteria: ROA (return on assets), ROE (return on equity), ROS (return on sales) and value added per employee and formulated three basic research hypotheses:

- $\quad \mathrm{H}_{0}$ : There are no performance differences between specific types of corporate strategies.

- $\quad \mathrm{H}_{0}$ : There are no performance differences between external and internal growth strategies.

- $\mathrm{H}_{0}$ : There are no performance differences between companies regarding the ownership structure.

The author defined three basic criteria to determine whether two businesses are related or not. In order for one business to be related to another and to consider diversification as related, at least two of the following three criteria had to be fulfilled: (1) similar type of markets served, (2) similar type of products sold and, (3) similar technology used in production.

\section{THEORETICAL BACKGROUND}

A fundamental part of any firm's corporate strategy is its choice of what portfolio of businesses it is to compete in. There are two main types of diversification: related diversification and unrelated diversification. Related diversification is diversification in a new business activity that is linked to a company's existing business activity. In most cases, these linkages are based on manufacturing, marketing or technological synergies. The diversified company can create value in three main ways. First, by acquiring and restructuring poorly run enterprises. Second, by transferring competencies among businesses. Third, by realising economies of scope Table 1 lists the sources of value and costs for each strategy.

Table 1: Comparing Related and Unrelated Diversification

\begin{tabular}{|l|l|l|}
\hline \multicolumn{1}{|c|}{ Strategy } & \multicolumn{1}{|c|}{ Ways of Creating Value } & \multicolumn{1}{c|}{ Source of Bureaucratic Costs } \\
\hline Related diversification & Restructuring & Number of businesses \\
\hline & Economies of scope & \\
\hline & Transferring skills & Co-ordination among businesses \\
\hline Unrelated diversification & Restructuring & Number of businesses \\
\hline
\end{tabular}

Scholars have analysed the performance of related vs. unrelated diversification strategies. The empirical evidence on this issue is however mixed. The author can identify at least three different groups of authors with contradicting results. According to the lion's share of the academic literature the diversification strategy should reflect the superiority of related diversification over unrelated diversification (Singh, Montgomery, 1987; Rumelt, 1974). This first group of scholars found that well-managed organisations had used a »sticking to the knitting « strategy (Collis, Montgomery, 1998). Another group of scholars argues that performance differences depend on the characteristics of the markets in which firms operate rather than on the strategic relationship between existing and new businesses (Lecraw, 1984; Bettis, Hall, 1982). However, the third group of scholars found that unrelated diversification performs better than related version (Chatterjee, 1986; Little, 1984).

On the other hand, some scholars suggest that the traditional ways of measuring relatedness between two businesses is incomplete because it ignores the strategic importance and similarity of the underlying assets residing in these businesses (Markides, Williamson, 1994). Researchers have traditionally regarded relatedness as being limited primarily because it has tended to equate the benefits of relatedness with the static exploitation of economies of scope, thus ignoring the main contribution of related diversification to long-run competitive advantage. This is the 
potential of a firm to expand its stock of strategic assets and create new ones more rapidly at a lower cost than its rivals which are not diversified across related businesses.

According to the Porter study of 33 prestigious US companies, each company entered an average of 80 new industries and 27 new fields. Just over $70 \%$ of the new entries were acquisitions, $22 \%$ were start-ups, and only $8 \%$ were joint ventures (Porter, 1987). Entry into new product-markets, which represents diversification for the existing firm, may provide an important source of future growth and profitability. In his study Porter identified four concepts of corporate strategy that have been put into practice: portfolio management, restructuring, transferring skills and sharing activities. The concepts are not always mutually exclusive, but each rests on a different mechanism by which the corporation creates shareholder value and each requires the diversified company to manage and organise itself in a different way. The first two require no connections among business units, the second two depend on them.

Research of 358 executives over a 45 -year period revealed growth to be the most frequently used corporate strategy (Hill, Jones, 1998). This strategy has been used six times more often than stability and seven times more often than retrenchment. Growth strategies are extremely popular because most executives tend to equate growth with success (Wheelen, Hunger, 1999). Corporations in the dynamic environment must grow in order to survive. Growth is a very seductive strategy for at least three key reasons:

- $\quad$ To exploit economies of scale, as well as the effect of the experience curve.

- $\quad$ A growing firm can cover up mistakes and inefficiencies more easily than a stable one. Larger firms also have more clout and are more likely to receive support in the case of impending bankruptcy.

- $\quad$ Growth, per se, is exciting and ego-enhancing for CEOs. A growing corporation tends to be seen as a winner.

The factors that determine why and how one business outperforms another have been the subject of considerable research. In general, the debate has centred on competitive positioning, resource- or competence-based theory and knowledge-based approaches. The first of these approaches, the subject of Porter's work, concentrates on developing a strategic framework by viewing a firm in the context of its environment (Porter, 1985). The second sees superior performance as a consequence of the special resources of an individual organisation (Grant, 1991). This approach is called the resource-based theory. The third approach is based on core competencies that can be defined as a combination of resources and capabilities that are unique to a specific organisation and which are responsible for generating its competitive advantage (Prahalad, Hamel, 1990). The knowledge-based theory is the fourth approach focused on the importance of knowledge management and organisational learning in building and maintaining a competitive edge (Whitehill, 1997). Although each of these approaches provides a method by which superior performance can be investigated, it is the knowledge-based approach that in more recent times offers the best perspective from which the determinants of company's competitive advantage can be analysed. Successful corporate strategies are based on certain competitive advantages of companies that can be explained by these theories.

Some management studies have suggested that managers make different decisions when owners are actively involved in the firm (owner-controlled) versus the situation where paid managers are relatively free to set the firm's strategy (Tosi, Katz, Gomez, 1997; McEachern, 1975). Managers and internal owners have managed to forge specific coalitions in many companies that are controlled by insiders. These companies are in fact controlled by managers and they behave differently to companies controlled by strategic outside investors. An insiderdominated firm may generate neither the resources needed for restructuring activities, such as investment, nor have the incentive to sell the firm to outsiders who have those resources (Blanchard, Anghion, 1995). Prašnikar and Svejnar (1998, page 19) found some strong arguments in their research to support this thesis regarding the role of insiders in Slovenian companies. Therefore, the author decided to compare the performance of companies regarding the ownership structure also.

Rumelt argued (1984) that a firm's competitive position is defined by a bundle of unique resources and relationships with competitive advantage arising from the sources of potential rents ranging from changes in technology and consumer tastes to innovation and legislation. The ability of a firm to develop and sustain a competitive advantage from these sources depends on its ability to develop isolating mechanisms. These can take the 
form of specialised assets and resources, especially those that provide specialised information, enhance brand name, image and reputation, and restrict entry. It is evident that core competencies and the isolating mechanism are heavily dependent on knowledge. Therefore, the modern business literature emphasises knowledge as the most critical success factor of companies. Sustaining a competitive edge in a dynamic and volatile environment relies on an organisation generating new knowledge more rapidly than its competitors.

\section{BUSINESS ENVIRONMENT}

Slovenia is an open, export oriented economy and is committed to open markets. It is an integrative part of common internal EU market. Potential foreign investors outside EU have been used Slovenian economy as a starting point for penetrating internal EU market. Slovenia survived relatively well the first impact of the financial crisis and Slovenia is not in the recession. This is attributable to the banks' limited exposure and a low level of household debt. However, the most recent data show that lower demand and tightening of financing conditions, the changes in the international environment have begun to affect the Slovenian economy. Lower growth of exports, industrial production, construction activities and retail trade resulted in a considerable deceleration of economic activity and negative GDP growth in the last two months of 2008. The most pronounced slowdown was in labor intensive sectors and manufacturing such as household appliances and automotive sectors, which are also important for exports. In 2008 the GDP increased by 3.5\%, which was much lower than in 2007 in which $6.8 \%$ rate of economic growth was recorded. By the end of 2008 the rate of inflation was $1.8 \%$. The Slovenian government acted quickly to mitigate the effects of the crisis. In December 2008 it adopted the first stimulus package consisting of measures to stabilize financial markets and to improve the growth potential of the economy and its resilience. The second package upgraded the first package with concrete measures in February 2009.

Economic policy makers believe that protectionist tendencies should be avoided in the times of crisis. The anti-crisis measures do not discriminate between domestic and foreign commercial entities. Slovenia is committed to free capital movements, which have brought tangible benefits, including outward investments which have been growing consistently and are an important instrument of market diversification as well as growth of enterprises, especially in the services industry. Slovenia is committed to continue with the programmes of privatisation of companies in direct or indirect state ownership, although now is not the best time for these activities. There is still a process of accelerated exit of the state from company ownership in the portfolios of the state funds, i.e. the capital fund (KAD) and the restitution fund (SOD). In those companies that will remain in state-ownership with an important share, considerable improvements are taking place in corporate governance in accordance with the Principles and Guidelines of the OECD on corporate governance, especially of state-owned enterprises.

Inward investments into Slovenia have been following a well established pattern. Having in mind the size of the economy, foreign investors have achieved good results. They are as a rule long-term oriented, rather than short-term profit oriented. Investments are not based on low-labor costs but on technical skills and relative geographic position of Slovenia. Most existing foreign investments have expanded in the course of years. A recent survey has been conducted to gauge the degree of satisfaction of foreign investors in Slovenia in which the question of motives for investing in Slovenia, as a small economy is very revealing. By structure, manufacturing foreign subsidiaries are distinctly export oriented.

Gradual liberalization of FDI, the relaxation of policies and legislative frameworks, is apparent through the consistent rise in FDI stock in Slovenia. Stock of inward FDI increased from EUR 1.3 billion in 1995 to EUR 9.5 billion in 2007. As a share of GDP it grew from $9.5 \%$ in 1995 to $27.7 \%$ in 2007. Likewise, outward FDI stock has grown at a much faster pace from only EUR 382 million in 1995 to EUR 4.8 billion in 2007. As a share of the GDP, it grew from only $2.6 \%$ in 1995 to $14.2 \%$ in 2007. Slovenia has one of the highest outward FDI stock to GDP ratios among the new EU member states. In 2005 - 2007, the FDI outflows from Slovenia surpassed the inflows, making Slovenia a net direct investor abroad. Investment trends in Slovenia continue to be positive with a steady growth. It is important to note that in recent years, standards and conditions that help attract new investments have improved significantly. This is particularly true in the area of public governance, accountability in public decision-making, and especially public consultations and regulatory impact assessment which have become obligatory for all government authorities. These trends have increased the degree of transparency and market openness. 
In the area of corporate governance, the Government increased its activities to ensure better compliance with the law and standards of responsible and reasonable business conduct, including of Slovenian company activities abroad. An open dialogue on the standards of business conduct, also fueled by the current crisis circumstances, has been ongoing for some time. Steps are being taken to better define the role of the State in the economy and that of private business initiative as well as respective responsibilities. The awareness that basic principles of sound corporate governance, such as transparency, disclosure, the observance of the law and fairness, are strong determinants for well-based investment decisions, for the confidence of investors, for the reduced cost of capital and the development of sustained sources of financing. This is clearly understood in Slovenia.

In the area of intellectual property rights, Slovenia has achieved an appropriate level of standards in supporting policies that protect these rights, which encourage innovation and the development of a knowledge-based society. Slovenia is also an exporter of knowledge, significantly through the private sector activity abroad. At the same it is aware of the remaining challenges, particularly in the area of enforcement, such as those in relation to the length of court proceedings and backlogs and issuing decisions. Measures have been taken to reduce the delays and streamline the procedures in order to increase efficiency.

\section{RESULTS OF THE STUDY}

Most companies involved in this research have been developing one form of growth strategy: market development strategy, product-market diversification strategy or the strategy of conglomerate diversification (see Table 2). This finding is consistent with the research results in other developed economies. By comparing the performance of various types of corporate strategies, the following conclusions were drawn:

- $\quad \mathrm{H}_{0}$ is rejected by comparing the performance of unrelated diversification with the related diversification strategy $(\mathrm{p}<0.05)$. There are statistically significant performance differences regarding ROA, ROE and value added per employee between the related diversification on one hand and unrelated diversification strategy on the other. $\mathrm{H}_{0}$ is therefore rejected at very low "p" level.

- $\quad$ The results indicate that unrelated diversification strategy outperforms related diversification strategy regarding return on sales.

- $\quad$ Retrenchment strategy is outperformed by the other two types regarding all four criteria (ROA, ROE, ROS and value added). The performance differences are statistically significant at low levels $(p<0.05)$ when comparing performance by the first three criteria. The differences are statistically significant at a higher level ( $p>0.05$ ) when comparing value added per employee, but $\mathrm{H}_{0}$ cannot be rejected.

- Companies with international ownership structure performed better than companies without foreign owners regarding all four criteria $(\mathrm{p}<0.05)$. In other words, foreign owners had positive influence on the performance of companies. Companies controlled by insiders behaved differently to companies controlled by strategic outside investors. In many cases, the insider-dominated firms generated neither the resources needed for restructuring activities, such as investment, nor have the incentive to sell the firm to outsiders who have those resources. Firms owned by strategic outsiders responded better to the global economic crisis.

Table 2: Structure of the companies regarding the type of the corporate strategy

\begin{tabular}{|c|c|}
\hline $\begin{aligned} \text { Type of the corporate strategy } \\
\end{aligned}$ & Share of companies (in \%) \\
\hline Product-market diversification & 26.1 \\
\hline Market development & 23.2 \\
\hline Conglomerate diversification & 20.3 \\
\hline Product development & 15.9 \\
\hline Divestment & 14.5 \\
\hline
\end{tabular}

This study reveals that $40.6 \%$ of companies diversified through external means, $36.2 \%$ diversified through internal means, while $23.2 \%$ diversified through both internal and external methods. Internal growth and joint ventures are the most important forms of diversification (see Table 3). Acquisitions are still one of the most popular growth strategies. On the other hand, the track record of mergers and acquisitions in the developed economies is not 
very encouraging (Dess, Picken, Janney, 1998). There appears to be no statistically significant performance differences between companies regarding the external or internal growth strategy. The author could not reject the $\mathrm{H}_{0}$ hypothesis at a statistically significant low " $\mathrm{p}$ " level $(\mathrm{p}>0.05)$. Some other scholars have come to the same conclusions in their studies (Lamont, Anderson, 1985). Companies also tend to develop various forms of long-term strategic co-operation. This process can be crucial for developing competitive advantages. The most important motives for the corporate strategy that has been developing in Slovenian companies are: to increase or maintain market share and to improve cost efficiency through rationalising operating costs. Companies are trying to maintain their competitive advantage that is obviously partly based on economies of scale.

\section{INTERNATIONALISATION STRATEGY}

The authors can identify the specific pattern of ongoing internationalisation. Direct and indirect exports prevail in the first phase of internationalisation. This is the initial entry of the market. Success in the first stage leads the parent corporation to believe that a stronger presence is needed in the target market. Subsidiaries of the parent were formed in the second phase. In some cases, the author also identified joint ventures between the parent and local companies. Most companies have autonomous subsidiaries owned by the parent that is developing a specific market strategy in the local market. The characteristic of the third phase was usually the formation of an independent local company that gradually also takes over some other functions. In this phase, companies often develop some forms of a strategic partnership with local companies that can lead to acquisition in the near future. This pattern of the internationalisation of business activities is characteristic of those Slovenian companies seeking to gain as large a share as possible in Southeast European markets. 94.2\% of companies are internationalised. The rest of companies are oriented to the domestic market. These international business dynamics reflect the changing international business environment and the organisational response of companies whose competitive strategies increasingly involve crossing national borders. As soon as at least one competitor gains from taking an international strategic position then competitive forces begin to change, with the leading firms in the market needing to respond. The dynamic nature of such responses inevitably results in increased international exposure, requiring co-ordination and relationships with suppliers, distributors and customers across functions and geographical boundaries. More detailed analyses of the internationalisation process showed that the companies are trying to develop a more complex form of international business activities (see Table 3). The prevailing strategic orientation of Slovenian companies is to build up international strategic alliances. This should lead to global competitive advantages through long-term business co-operation. Companies are keen on green-field investment as well as on acquisitions. The most important motives that determine the internationalisation business strategy are: to increase growth and performance of the company (71\%); to realise various operative synergies (43.5\%) and, last but not least, a defensive strategy against competitors. Internationalisation of a company leads to cost reduction through the global configuration and coordination of its business activities.

Table 3: Strategies of internationalisation developed by the companies involved in this research

\begin{tabular}{|l|c|}
\hline \multicolumn{1}{|c|}{ Strategy of internationalisation } & Share of companies in Slovenia (in \%) \\
\hline Greenfield investment & 56.5 \\
\hline Acquisition of foreign companies & 44.9 \\
\hline Direct export & 39.1 \\
\hline Long-term production co-operation & 36.2 \\
\hline Joint ventures & 34.8 \\
\hline Franchising & 15.9 \\
\hline Other forms of strategic alliances & 14.5 \\
\hline Licensing & 13.0 \\
\hline Indirect export & 7.2 \\
\hline
\end{tabular}

The author found that managerial competencies (4.28) as well as competencies based on a specific business process (4.19) are the most important. Competencies based on inputs are less important (3.11). The same is true for competencies based on outputs (3.12) that are embodied in products or somehow represented in services. $68.1 \%$ of companies are developing a corporate strategy based on core competencies. The author identified four large groups of core competencies that are the cornerstones of the corporate strategies developed. The first group was based on 
the position of a firm within the local industry. These competencies are financial power, the company's image, location, bargain power with regard to the suppliers and familiarity with the local environment. The second group of core competencies was based on technology management (know-how, product development, and technology development), whereas the third group of core competencies was based on the quality of business processes and products. The fourth group of core competencies was based on the employees (management, experts, training process) as well as on the organisational culture in the firm. Familiarity with the concept of knowledge management played important role in the internationalisation process (see Table 4). The author may argue that top management should in fact be involved in the knowledge management process in order to successfully internationalise business activities. However, a company needs to develop more innovative types of knowledge for a sustainable competitive advantage.

Table 4: The importance of knowledge for a company's competitive advantage

\begin{tabular}{|l|c|}
\hline \multicolumn{1}{|c|}{ Type of knowledge } & Importance of a specific type of knowledge in Slovenia \\
\hline Human capital & $4.32(0.67)^{*}$ \\
\hline Organisational culture & $3.81(0.69)^{*}$ \\
\hline Familiarity with the concept of knowledge management & $3.68(1.01)^{*}$ \\
\hline Structural capital & $3.66(0.89)^{*}$ \\
\hline Knowledge developed through strategic alliances & $3.41(0.87)^{*}$ \\
\hline ISO standards & $2.98(1.21)^{*}$ \\
\hline Patents, licences, models & $2.61(1.18)^{*}$ \\
\hline
\end{tabular}

*Standard deviation

Scale: 1 - not important, 5 - very important

\section{CONCLUSION}

Slovenia is an open, export oriented economy and is committed to open markets. It is an integrative part of common internal EU market. Potential foreign investors outside EU have been used Slovenian economy as a starting point for penetrating internal EU market. By comparing the performance of various types of corporate strategies the author found that related diversification performed better than unrelated one. There are statistically significant performance differences regarding ROA, ROE and value added per employee between the related diversification on one hand and unrelated diversification strategy on the other. Retrenchment strategy is outperformed by the other two types regarding all four criteria (ROA, ROE, ROS and value added). The performance differences are statistically significant at low levels $(\mathrm{p}<0.05)$ when comparing performance by the first three criteria. The differences are statistically significant at a higher level $(\mathrm{p}>0.05)$ when comparing value added per employee but the $\mathrm{H}_{0}$ hypothesis cannot be rejected. By comparing the performance of companies regarding the ownership structure the author found that those companies with more international ownership structure performed better. In other words, foreign owners had positive influence on the performance of companies.

The author identified the specific pattern of internationalisation of companies' business activities. Direct and indirect exports prevail in the first phase of internationalisation. This is the initial entry of the market. Success in the first stage leads the parent corporation to believe that a stronger presence is needed in the target market. Subsidiaries of the parent were formed in the second phase. In some cases, the author also identified joint ventures between the parent and local companies. Most companies have autonomous subsidiaries owned by the parent that is developing a specific market strategy in the local market. The characteristic of the third phase was usually the formation of an independent local company that gradually also takes over some other functions. In this phase, companies often developed some forms of a strategic partnership with local companies that could lead to acquisition in the near future.

\section{AUTHOR INFORMATION}

Matej Lahovnik is an associate professor at the Faculty of Economics in Ljubljana. In 1999, he was a visiting scholar at Indiana University, Kelley School of Business, USA. His current research topic is restructuring process in Central and Eastern European economies. He has participated at several international conferences on the 
restructuring processes of enterprises in the transition economies. In 2004 and in the period 2008-2010, he was a minister of the economy in the Slovenian government.

\section{REFERENCES}

1. Bettis, R. A and Hall, K. W., (1982), Diversification Strategy, Accounting Determined Risk and Accounting Determined Return, Academy of Management Journal, Vol. 25 (2), 254-264.

2. $\quad$ Blanchard, O. and Aghion, P. (1995), On Insider Privatisation, MIT press, Boston.

3. Chatterjee, S., (1986), Types of Synergy and Economic Value: The Impact of Acquisitions on Merging and Rival Firms, Strategic Management Journal, Vol. 7 (2), 119-139.

4. Collis, D. J and Montgomery, A. C., (1998), Creating Corporate Advantage, Harvard Business Review, Vol. 76 (3), 71-83.

5. Dess, G. D., Picken, C. J. and Janney, J. J., (1998), Subtracting Value by Adding Businesses, Business Horizons, Vol. 41 (1), 9-18.

6. Grant R., (1991), The resource-based theory of competitive advantage: implications for strategy formulation, California Management Review, Vol. 33 (1), 114-135.

7. Hill, W. L. and Jones, R. G., (1998), Strategic Management: An Integrated Approach, Houghton Mifflin Company, Boston, MA.

8. Lamont, B. T. and Anderson, C. A., (1985), Mode of Corporate Diversification and Economic Performance, Academy of Management Journal, Vol. 28 (4), 926-936.

9. Lecraw, D. J. (1984), Diversification Strategy and Performance, Journal of Industrial Economics, Vol. 33 (2), 179-198.

10. Little, R., (1984), Conglomerates are doing better than you think, Fortune, Vol. 109 (11), 34-40.

11. Markides, C. and Williamson J. P., (1994), Related Diversification, Core Competences and Corporate Performance, Strategic Management Journal, Vol. 15 (Special Issue), 149-165.

12. McEachern, W. (1975), Managerial Control and Performance, Lexington Books, Lexington.

13. Porter, M., (1985), Competitive Advantage, Free Press, New York.

14. Porter, M., (1987), From competitive advantage to corporate strategy, Harvard Business Review, Vol. 65 (3), 43-59.

15. Prahalad, C. and Hamel, G., (1990), The core competence of the corporation, Harvard Business Review, Vol. 68 (3), 79-91.

16. Prašnikar, J. and Svejnar, J. (1998), Investment, Wages and Ownership during the Transition to a Market Economy: Evidence from Slovenian Firms, Working Papers Series, No. 79, Department of Economics, Ljubljana.

17. Pučko, Danijel and Lahovnik, Matej, (1997), Managers in the transformation process of Eastern Europe, Journal for East Euopean Management studies, Vol. 2 (4), 360-376.

18. Rumelt, R., (1984), Towards a strategic theory of the firm, in R. Lamb (ed.), Competitive Strategic Management, Prentice-Hall, Englewood Cliffs, NJ.

19. Rumelt, R., (1974), Strategy, Structure and Economic Performance. Harvard Business School, Cambridge, MA.

20. Singh, H. and Montgomery, C. A., (1987), Corporate acquisition strategies and economic performance, Strategic Management Journal, Vol. 8 (4), 377-386.

21. Tosi, H., Katz, J. and Gomez, L. M. (1997), Disaggregating the agency contract: The effects of monitoring, incentive alignment, and term in office on agent decision making, Academy of Management Journal, Vol. 40 (3), 584-602.

22. Wheelen, T. L. and Hunger D. J., (1999), Strategic Management, Addison-Wesley Publishing Company, New York, NY.

23. Whitehill, M., (1997), Knowledge-based strategy to deliver sustained competitive advantage, Long Range Planning, Vol. 30 (4), 621-627. 